\title{
PENDEKATAN KOMUNIKATIF DALAM PEMBELAJARAN BAHASA INDONESIA DI SD/MI
}

\author{
Idah Faridah Laily \\ *Dosen Jurusan PGMI FITK IAIN Syekh Nurjati Cirebon \\ Email:idah@yahoo.co.id
}

\begin{abstract}
ABSTRAK
Dalam mengajar, guru mungkin menggunakan lebih dari satu strategi dan pendekatan. Mereka memilih teknik dan materi berdasarkan sejumlah pendekatan untuk kebutuhan siswa secara individu dikelas. Tidak ada satu pun pendekatan terbaik untuk siswa atau guru. Pada prosedur pembelajaran pendekatan komunikatif, terdapat beberapa garis besar pembelajaran yang harus diperhatikan yakni penyajian dialog singkat, pelatihan lisan dialog yang disajikan, penyajian tanya-jawab, penelaahan dan pengkajian, penarikan simpulan, aktifitas interpretatif, aktifitas produksi lisan, pemberian tugas, dan pelaksanaan evaluasi.

Sementara itu, beberapa aspek yang harus diperhatikan kaitannya dengan pendekatan komunikatif adalah teori bahasa, teori belajar, tujuan, silabus, tipe kegiatan, peranan guru, peranan siswa, dan peranan materi. Adapun dalam penerapan pendekatan komunikatif ini, ada dua hal yang harus diperhatikan, yakni tujuan pembelajaran dan kurikulum yang digunakan. Adapun yang termasuk dalam strategi pembelajaran bahasa Indonesia berdasarkan pendekatan komunikatif adalah pengorganisasian kelas serta metode dan teknik belajar mengajar.
\end{abstract}

\section{PENDAHULUAN}

Bahasa Indonesia merupakan mata pelajaran yang membelajarkan siswa untuk berkomunikasi dengan baik dan benar. Komunikasi ini dapat dilakukan baik secara lisan maupun tulisan. Dengan kesimpulan tersebut, maka standar kompetensi mata pelajaran bahasa Indonesia merupakan kualifikasi kemampuan minimal siswa yang menggambarkan penugasan, pengetahuan, ketrampilan berbahasa, sikap positif terhadap bahasa dan sastra Indonesia. Standar kompetensi ini merupakan dasar bagi siswa untuk memahami dan merespon situasi lokal, regional, nasional, dan global.

Standar kompetensi mata pelajaran bahasa Indonesia dirumuskan karena, diharapkan mampu menjadikan: (1) siswa dapat mengembangkan potensinya sesuai dengan kemampuan, kebutuhan, dan minatnya, serta dapat menumbuhkan 
penghargaan terhadap hasil karya kesusastraan dan hasil intelektual bangsa sendiri, (2) guru dapat memusatkan perhatian kepada pengembangan kompetensi bahasa siswa dengan menyediakan berbagai kegiatan berbahasa, (3) guru lebih mandiri dan leluasa dalam menentukan bahan ajar kebahasaan sesuai dengan kondisi lingkungan sekolah dan kemampuan siswanya, (4) orang tua dan masyarakat dapat secara aktif terlibat dalam pelaksanaan program kebahasaan di sekolah, (5) sekolah dapat menyusun program pendidikan kebahasaan sesuai dengan keadaan siswa dengan sumber belajar yang tersedia, dan (6) daerah dapat menentukan bahan dan sumber belajar kebahasaan dengan kondisi kekhasan daerah dengan tetap memperhatikan kepentingan nasional (BSNP:2006).

Pembelajaran bahasa Indonesia memiliki peranan yang sangat penting dalam membentuk kebiasaan, sikap, serta kemampuan siswa untuk tahap perkembangan selanjutnya. Selain itu, pembelajaran harus dapat membantu siswa dalam pengembangan kemampuan berbahasa di lingkungannya, bukan hanya untuk berkomunikasi, namun juga untuk menyerap berbagai nilai serta pengetahuan yang dipelajarinya. Melalui bahasa, siswa mampu mempelajari nilainilai moral atau agama, serta nilai-nilai sosial yang berlaku di masyarakat, melalui bahasa, siswa juga mampu mempelajari berbagai cabang ilmu.

Bahasa memungkinkan manusia untuk saling berkomunikasi, saling berbagi pengalaman, saling belajar dari yang lain, dan untuk meningkatkan kemampuan intelektual dan kesusasteraan merupakan salah satu sarana untuk menuju pemahaman tersebut. Standar kompetensi mata pelajaran Bahasa Indonesia adalah salah satu program yang bertujuan untuk mengembangkan pengetahuan, keterampilan berbahasa peserta didik, serta sikap positif terhadap Bahasa dan Sastra Indonesia.

Belajar bahasa pada hakikatnya adalah belajar berkomunikasi. Oleh karena itu, pembelajaran bahasa Indonesia diarahkan untuk meningkatkan kemampuan siswa dalam berkomunikasi. Salah satu keberhasilan suatu pembelajaran ditentukan oleh pendekatan yang digunakan oleh guru dalam kegiatan pembelajaran tersebut. Banyak pendekatan pembelajaran yang dapat digunakan 
dan guru harus cermat dalam memilih pendekatan mana yang cocok digunakan untuk lingkungannya.

Mencermati kompetensi kebutuhan siswa untuk dapat berkomunikasi dalam situasi yang sebenarnya, Sugono mengatakan pembelajaran bahasa sebagai alat komunikasi akan menarik minat siswa karena siswa didesak oleh kebutuhannya untuk berkomunikasi dengan orang lain. Oleh karena itu, untuk memenuhi atau meningkatkan keterampilan menggunakan bahasa sebagai alat komunikasi itu, pengajaran bahasa yang paling tepat adalah menggunakan pendekatan komunikatif.

Pendekatan mengacu pada seperangkat asumsi yang saling berkaitan dengan sifat bahasa, serta pengajaran bahasa. Pendekatan merupakan dasar teoritis untuk suatu metode. Asumsi tentang bahasa bermacam-macam, antara lain asumsi menganggap bahasa sebagai kebiasaan, ada pula yang menganggap bahasa sebagai suatu sistem komunikasi yang pada dasarnya dilisankan, dan ada lagi yang menganggap bahasa sebagai seperangkat kaidah. Pendekatan dalam pembelajaran bahasa Indonesia dipandang sesuai dengan seperangkat asumsi yang saling berkaitan, yakni pendekatan kontekstual, pendekatan komunikatif, pendekatan terpadu, dan pendekatan proses. Menurut Aminuddin pendekatan merupakan seperangkat wawasan yang secara sistematis digunakan sebagai landasan berpikir dalam menentukan metode, strategi, dan prosedur dalam mencapai target hasil tertentu sesuai dengan tujuan yang telah ditetapkan.

Pendekatan komunikatif merupakan pendekatan yang dilandasi oleh pemikiran bahwa kemampuan menggunakan bahasa dalam berkomunikasi merupakan tujuan yang harus dicapai dalam pembelajaran bahasa. Tampak bahwa bahasa tidak hanya dipandang sebagai seperangkat kaidah, tetapi lebih luas lagi, yakni sarana berkomunikasi. Ini berarti, bahasa ditempatkan sesuai dengan fungsinya, yakni fungsi komunikasi. Pendekatan komunikatif adalah suatu pendekatan yang bertujuan untuk meningkatkan keterampilan siswa dalam berkomunikasi, menekankan pembinaan dan pengembangan kemampuan komunikatif siswa. Penerapan pendekatan komunikatif sepenuhnya dilakukan oleh siswa (student centre) sedangkan guru hanya sebagai fasilitator. Dengan 
demikian siswa akan mampu bercerita, menanggapi masalah, dan mengungkapkan pendapatnya secara lisan dengan bahasa yang runtut dan mudah dipahami.

\section{PEMBELAJARAN BAHASA INDONESIA DI SD/MI}

Dalam konteks pendidikan, guru mengajar supaya peserta didik dapat belajar dan menguasai isi pelajaran hingga mencapai sesuatu objektif yang ditentukan (aspek kognitif), juga dapat mempengaruhi perubahan sikap (aspek afektif), serta keterampilan (aspek psikomotor) seseorang peserta didik. Pengajaran memberi kesan hanya sebagai pekerjaan satu pihak, yaitu pekerjaan guru saja. Sedangkan pembelajaran juga menyiratkan adanya interaksi antara guru dengan peserta didik. Pembelajaran merupakan kegiatan belajar agar siswa dapat mempelajari sesuatu dengan cara efektif dan efisien. Dalam pembelajaran Bahasa Indonesia kelas awal ini, peserta didik dituntut untuk mampu belajar mengenal huruf abjad, membaca, mendengarkan dan menulis. Sedangkan pembelajaran Bahasa Indonesia Kelas Lanjut sudah harus mampu mulai bisa mengarang dan menyimak atau mendengarkan apa yang guru jelaskan. Belajar bahasa pada hakikatnya adalah belajar komunikasi. Oleh karena itu, pembelajaran bahasa Indonesia diarahkan untuk meningkatkan kemampuan siswa dalam berkomunikasi antara satu dengan yang lain.

Manusia sebagai mahluk sosial tidak dapat dipisahkan dari kegiatan saling berkomunikasi dan bentuk komunikasi manusia merupakan yang paling sempurna daripada binatang, karena manusia dapat melakukannya melalui berbagai sarana dan prasarana yang ada. Untuk berkomunikasi manusia memerlukan sautu media, terutama yaitu bahsa. Oleh karenanya setiap masyarakat mempunyai suatu media untuk berinteraksi dengan yang lainnya. Bahasa merupakan alat untuk berkomunikasi dengan orang lain, tercakup semua cara untuk berkomunikasi, dimana pikiran dan perasaan dinyatakan dalam bentuk lambing atau symbol untuk mengungkapkan sesuatu pengertian, seperti dengan menggunakan lisan, tulisan, isyarat, bilangan, lukisan dan mimik muka. Bahasa merupakan faktor hakiki yang membedakan manusia dengan hewan. Bahasa merupakan anugerah dari Allah SWT, yang dengannya manusia dapat mengenal atau memahami dirinya, sesama 
manusia, alam dan penciptanya serta mampu memposisikan dirinya sebagai mahluk berbudaya dan mengembangkan budayanya. Tiap individu dituntut untuk memiliki kemampuan menyatakan atau mengekspresikan pikirannya dan menangkap pemikiran orang lain melalui bahasa, sehingga komunikasi menjadi efektif. Anak-anak lebih dapat mengerti apa yang dikatakan orang lain daripada mengutarakan pikiran dan perasaan mereka dengan kata-kata. Semakin matang organ-organ yang berkaitan dengan proses berbicara seperti alat bicara dan pertumbuhan atau perkembangan otak, anak semakin jelas dalam mengutarakan kemauan, pikiran maupun perasaannya melalui ucapan atau bahasa. Hal itu tidak lepas ari pengaruh lingkungan, terutama orang tua atau keluarga. Anak yang selalu mendapat motivasi positif akan terpacu untuk mengembangkan potensi bicaranya.

Sebagai sarana untuk berkomunikasi dengan orang lain, bahasa merupakan media yang sangat signifikan bagi proses perkembangan siswa didik. Sarana ini merupakan upaya untuk menyatakan pikiran, perasaan dan emosi seseorang yang juga mencakup pengungkapan dalam bentuk lambang atau simbol.

Bagi anak usia sekolah dasar, perkembangan bahasa meliputi beberapa tahap, yaitu:

a. Tahap pemahaman, yaitu proses identifikasi dan mendefenisikan obyek yang ditemukan dengan kategorisasi-kategorisas sederhana dan mudah dipahami.

b. Tahap perbendaharaan kata yang diupayakan melalaui penghafalan kata dan penguasaan tanda baca.

c. Tahap membuat kalimat, yaitu dalam bentuk memberi perintah dan mengapresiasikan kemauan-kemauan serta menyatakan pendapat dan ide-ide.

d. Ucapan, yaitu dengan melakukan percakapan atau dialog-dialog sederhana yang menginformasikan tentang lingkungan sekitarnya.

Belajar Bahasa Indonesia di sekolah merupakan pokok dari proses pendidikan di sekolah. Belajar merupakan alat utama dalam mencapai tujuan 
pembelajaran sebagai unsur proses pendidikan di sekolah. Untuk mencapai tujuan tersebut, kita harus mengetahui tujuan dan peran pembelajaran Bahasa Indonesia.

Penanaman bahasa Indonesia sejak dini adalah memberikan pelatihan dan pendidikan tentang bahasa Indonesia sejak anak masih kecil. Pelaksanaan pendidikan bahasa Indonesia pada anak dapat dilakukan melalui pendidikan informal, pendidikan formal, maupun pendidikan nonformal. Pendidikan informal dilakukan oleh keluarga di rumah. Pendidikan ini dilakukan saat anak berada di rumah bersama dengan keluarganya. Sedangkan pendidikan formal dilaksanakan di dalam lembaga pendidikan resmi mulai dari SD sampai dengan perguruan tinggi. Dalam pendidikan formal ini gurulah yang berperan penting dalam menanamkan pengetahuan akan bahasa Indonesia. Sedangkan pendidikan nonformal dilaksanakan di luar rumah dan sekolah, dapat melalui kursus, pelatihan-pelatihan, pondok pesantren dan lain sebagainya.

Tujuan mata pelajaran Bahasa Indonesia di SD/ Madrasah Ibtidaiyah yaitu

1. Berkomunikasi secara efektif dan efisien sesuai dengan etika yang berlaku, baik secara lisan maupun tulis.

2. Menghargai dan bangga menggunakan bahasa Indonesia sebagai bahasa persatuan dan bahasa negara.

3. Memahami bahasa Indonesia dan menggunakannya dengan tepat dan kreatif untuk berbagai tujuan.

4. Menggunakan bahasa Indonesia untuk meningkatkan kemampuan intelektual, serta kematangan emosional dan sosial.

5. Menikmati dan memanfaatkan karya sastra untuk memperluas wawasan, memperhalus budi pekerti, serta meningkatkan pengetahuan dan kemampuan berbahasa.

6. Menghargai dan membanggakan sastra Indonesia sebagai khazanah budaya dan intelektual manusia Indonesia.

\section{PENDEKATAN KOMUNIKATIF DALAM PEMBELAJARAN BAHASA INDONESIA DI SD/MI}


Istilah pendekatan dalam pembelajaran bahasa mengacu pada teori-teori tentang hakekat bahasa dan pembelajaran bahasa yang berfungsi sebagai sumber landasan/prinsip pengajaran bahasa. Teori tentang hakikat bahasa mengemukakan asumsi-asumsi dan tesisi-tesis tentang hakikat bahasa, karakteristik bahasa, unsurunsur bahasa, serta fungsi dan pemakaiannya sebagai media komunikasi dalam suatu masyarakat bahasa. Teori belajar bahasa mengemukakan proses psikologis dalam belajar bahasa sebagaimana dikemukakan dalam psikolinguistil. Pendekatan pembelajaran lebih bersifat aksiomatis dalam definisi bahwa kebenaran teori-teori linguistik dan teori belajar bahasa yang digunakan tidak dipersoalkan lagi. Dari pendekatan ini diturunkan metode pembelajaran bahasa. Misalnya dari pendekatan berdasarkan teori ilmu bahasa struktural yang mengemukakan tesis-tesis linguistik menurut pandangan kaum strukturalis dan pendekatan teori belajar bahasa menganut aliran behavioerisme diturunkan metode pembelajaran bahasa yang disebut Metode Tata Bahasa (Grammar Method).

Istilah pendekatan pembelajaran dapat diartikan sebagai titik tolak atau sudut pandang kita terhadap proses pembelajaran, yang merujuk pada pandangan tentang terjadinya suatu proses yang sifatnya masih sangat umum, di dalamnya mewadahi, menginsiprasi, menguatkan, dan melatari metode pembelajaran dengan cakupan teoretis tertentu. Dilihat dari pendekatannya, pembelajaran terdapat dua jenis pendekatan, yaitu: (1) pendekatan pembelajaran yang berorientasi atau berpusat pada siswa (student centered approach) dan (2) pendekatan pembelajaran yang berorientasi atau berpusat pada guru (teacher centered approach).

Pendekatan komunikatif adalah suatu pendekatan yang bertujuan untuk membuat kompetensi komunikatif sebagai tujuan pembelajaran bahasa, juga mengembangkan prosedur-prosedur bagi pembelajaran empat keterampilan berbahasa (menyimak, membaca, berbicara, dan menulis), mengakui dan menghargai saling ketergantungan bahasa.

Menurut Littiewood (dalam Rofi'uddin, 2009) pendekatan komunikatif didasarkan pada pemikiran bahwa: 
1) Pendekatan komunikatif membuka diri bagi pandangan yang luas dalam pembelajaran bahasa. Hal ini terutama menyebabkan orang melihat bahwa bahasa tidak terbatas pada tata bahasa dan kosa kata, tetapi juga pada fungsi komunikasi bahasa.

2) Pendekatan komunikatif membuka diri bagi pandangan yang luas dalam pembelajaran bahasa. Hal ini menimbulkan kesadaran bahwa pembelajaran bahasa, tidak cukup dengan memberikan kepada siswa bagaimana bentuk-bentuk bahasa itu, tetapi siswa harus mampu mengembangkan cara-cara menerapkan bentuk-bentuk itu sesuai dengan fungsi bahasa sebagai sarana komunikasi dalam situasi dan waktu yang tepat.

Pendekatan komunikatif merupakan pendekatan yang berlandaskan pada pemikiran bahwa kemampuan menggunakan bahasa dalam berkomunikasi merupakan tujuan yang harus dicapai dalam pembelajaran bahasa. Jadi pembelajaran yang komunikatif adalah pembelajaran bahasa yang memungkinkan peserta didik memiliki kesempatan yang memadai untuk mengembangkan kebahasaan dan menunjukkan dalam kegiatan berbahasa baik kegiatan produktif maupun reseptif sesuai dengan situasi nyata, bukan situasi buatan yang terlepas dari konteks.

Ciri-ciri utama pendekatan pembelajaran komunikatif ada dua kegiatan yang saling berkaitan yakni adanya kegiatan-kegiatan:

1) Komunikasi Fungsional

Terdiri atas empat yakni: mengolah informasi, berbagi dan informasi, berbagi informasi dengan kerja sama terbatas, dan berbagi informasi dengan kerja sama tak terbatas.

2) Kegiatan yang sifatnya interaksi sosial.

Terdiri dari 6 hal yakni: improvisasi, lakon-lakon pendek yang lucu, aneka simulasi (bermain peran), dialog dan bermain peran, siding-sidang konversasi dan diskusi, serta berdebat. 
Ciri-ciri pendekatan pembelajaran komunikatif, Menurut Brumfit dan Finocchiaro ciri-ciri pendekatan komunikatif yaitu: (1) Makna merupakan hal yang terpenting, (2) Percakapan harus berpusat di sekitar fungsi komunikatif dan tidak dihafalkan secara normal, (3) Kontekstualisasi merupakan premis pertama (4) Belajar bahasa berarti belajar berkomunikasi , (5) Komunikasi efektif dianjurkan, (6) Latihan atau drill diperbolehkan, (7) Ucapan yang dapat dipahami diutamakan, (8) Setiap alat bantu peserta didik diterima dengan baik, (9) Segala upaya untuk berkomunikasi dapat didorong sejak awal (10) Penggunaan bahasa secara bijaksana dapat diterima bila memang layak, (11) Terjemaah digunakan jika diperlukan peserta didik, (12) Membaca dan menulis dapat dimulai sejak awal (13) Sitem bahasa dipelajari melalui kegiatan berkomunikasi (14) Komunikasi komunikatif merupakan tujuan (15) Variasi linguistik merupakan konsep inti dalam materi dan metodologi, (16) Urutan ditentukan berdasarkan pertimbangan isi, fungsi, atau makna untuk memperkuat minat belajar , (17) Guru mendorong peserta didik agar dapat bekerja sama dengan menggunakan bahasa itu, (18) Bahasa diciptakan oleh peserta didik melalui mencoba dan mencoba, (19) Kefasihan dan bahasa yang berterima merupakan tujuan utama, (20) Peserta didik diharapkan dapat berinteraksi dengan orang lain melalui kelompok atau pasangan, lisan dan tulis, (21) Guru tidak bisa meramal bahasa apa yang akan digunakan peserta didiknya (22) Motivasi intrinsik akan timbul melalui minat terhadap halhal yang dikomunikasikan.

Pendekatan komunikatif berorientasi pada proses belajar-mengajar bahasa berdasarkan tugas dan fungsi berkomunikasi. Prinsip dasar pendekatan komunikatif ialah: a) materi harus terdiri dari bahasa sebagai alat komunikasi, b) desain materi harus menekankan proses belajar-mengajar dan bukan pokok bahasan, dan c) materi harus memberi dorongan kepada pelajar untuk berkomunikasi secara wajar.

Strategi belajar-mengajar dalam pendekatan komunikatif didasarkan pada cara belajar siswa/mahasiswa aktif, yang sekarang dikenal dengan istilah Student Centered Learning ( $S C L$ ). Cara belajar aktif merupakan perkembangan dari teori Dewey Learning by Doing (1854-1952) (lihat Pannen, dkk.2001:42). Dewey 
sangat tidak setuju dengan rote learning 'belajar dengan menghafal'. Dewey menerapkan prinsip-prinsip learning by doing, yaitu siswa perlu terlibat dalam proses belajar secara spontan / siswa terlibat secara aktif dalam proses belajarmengajar. $\neg$ Strategi Pembelajaran Bahasa Indonesia berdasarkan Pendekatan Komunikatif.

Dalam pembelajaran bahasa sebenarnya ada tiga tes yang dapat di gunakan yaitu tes distrik, tes integratif, dan tes pragmatik. Namun pada pendekatan konunikatif, tes yang cocok untuk di gunakan adalah tes integratif dan tes pragmatif. Yang termasuk tes integratif: menyusun kalimat, menafsirkan wacana yang dibaca atau didengar, memahami bacaan yang didengar atau dibaca. Dan menyusun kalimat yang disediakan. Sedangkan yang termasuk tec pragmatif: dikte, berbicara, paraphrase, dan menjawab pertanyaan

\section{IMPLEMENTASI KOMUNIKATIF DALAM PEMBELAJARAN BAHASA DI SEKOLAH DASAR}

Secara operasional, ciri-ciri pendekatan komunikatif tersebut dalam pengajaran seperti berikut:

1) Kegiatan komunikatif yang disajikan betul-betul yang diperlukan oleh siswa. Misalnya, kalau siswa tidak tahu tentang cara menanam padi, suruhlah ia mewawancarai petani, sehingga ia akan memperoleh informasi yang betul-betul dibutuhkan. Kalu siswa bertanya tentang sesuatu, tetapi sudah tahu jawabannya, ini bukan komunikasi, sebab tidak ada kesenjangan informasi (Hubard dalam Subyakto, 1989). Jadi, salah satu ciri pendekatan komunikatif adalagh adanya kekosongan informasi.

2) Untuk mendorong siswa mau belajar, Hendaknya guru memberikan kegiatan belajar yang bermakna. Misalnya, tugas yang diberikan guru agar mengganti satu bentuk kalimat ke bentuk kalimat yang lain yang tidak begitu bermakna bagi siswa misal nya Ibu memanggil adik, adik memanggil ibu . tugas yang bermakna, Misalnya siswa menulis pengalamanya atau menulis hasil kunjungan 
3) Materi dari Silabus kurikulum komunikasi di persiapkan setelah diadakan suatu analisis mengenai kebutuhan barbahasa.

4) Penekanan pendekatan komunikatip ialah pada pelayanan individu siswa.

5) Peran guguru adalah sebagai peranan. Ia fasilitato motivator bagi perkembangan individu siswa. Guru tidak selalu dibenarkan selalu mendominasi kelas karena yang dipentingkan ialah bagaimana siswa dapat di bimbing untuk berkomunikasi dengan wajar ( memiliki keterampilan berbahasa baik lisan maupun tulisan)

6) Materi interaksional siswa berperan menunjang komunikasi siswa secara aktif.materi ini terdiri atas tiga macam: materi berdasarkan teks ( bukubuku pelajaran). Materi berdasarkan tugas ( berupa tugas membuat peta perjalanan dari rumah ke sekolah melakukan tugas bermain peran) materi berdasarkan bahan otentik/relita ( materi yang diambil dari surat kabar,maja-lah,percakapan yang sesungguh nya dan sebagainya).

Berdasarkan uraian di atas, makna penerapan pendekatan komunikatif bertujuan agar siswa mampu berkomunikasi dan mampu menggunakan bahasa secara baik, benar, dan secara nyata dan wajar, serta dapat digunaan untuk berbagai tujuan dan keadaan. Di samping itu kemampuan komunikasi menuntut adanya kemampuan gramatik, kemampuan sosiolinguistik, kemampuan wacana, dan kemampuan strategi. Dalam proses pembelajaran, guru hanya berfungsi sebagai komunikator, fasilator, dan motivator. Sehubungan dengan itu, yang menjadi acuan adalah kebutuhan siswa untuk dapat berkomunikasi dalam situasi yang sebenarnya. Sugono (1993) mengatakan bahwa pembelajaran bahasa sebagai alat komunikasi akan menarik minat siswa karena siswa didesak oleh kebutuhannya untuk berkomunikasi dengan orang lain. Oleh karena itu, untuk memenuhi atau meningkatkan keterampilan menggunakan bahasa sebagai alat komunikasi itu, pembelajaran bahasa yang paling tepat adalah menggunakan pendekatan komunikatif. 
Canale (1983), Savignon (1983), Omaggio (dalam Syafe'ie, 1994) mengatakan kompetensi komunikasi itu didukung oleh penggunaan unsur-unsur berikut ini:

1. Pengetahuan dan penguasaan sistem kaidah gramatika (tata bahasa) yang meliputi: kaidah-kaidah pengucapan bunyi-bunyi bahasa serta ejaan dan tanda baca, kaidah pembentukan kata, kaidah penyusun kalimat, serta penguasaan kosa kata.

2. Penguasaan segi-segi sosiolingistik, berupa memahami kesesuaian penggunaan berbagai kosa kata dan kaidah gramatika untuk digunakan dalam berbagai fungsi komunikasi, seperti persuasi, deskripsi, narasi, memberikan perintah. Penguasaan segi-segi sosiolinguistik juga berupa kemampuan memilih ragam bahasa yang tepat dalam berkomunikasi dengan memperhatikan topik, hubungan antarperan komunikasi, suasana, serta latar komunikasi.

3. Penguasaan kewacanaan, merujuk pada kemampuan pengguna bahasa untuk menyelaraskan bentuk dan makna bahasa menuju pada terbentuknya wacana yang kohesif dan koheren, atau wacana yang memiliki kesatuan dan kepaduan yang tepat.

4. Penguasaan strategis komunikasi, berupa kemampuan menggunakan strategi nonverbal untuk mengatasi berbagai kesenjangan yang terjadi antara pembicara/penulis dengan pendengaran atau pembaca. Kesenjangan ini mungkin disebabkan oleh penguasaan bahasa yang lemah, kurangnya penguasaan konsep-konsep materi yang disampaikan, hubungan yang kurang serasi antara pembicara/penulis dan pendengar/pembaca.

Berdasarkan hal tersebut di atas, seorang yang telah memiliki potensi yang berupa kompetensi komunikatif diharapkan dapat menampilkan penggunaan bahasa secara lancar, baik, dan benar.

Langkah-langkah pembelajaran yang berlandaskan pendekatan komunikatif adalah sebagai berikut: 
1. Tahap persiapan, guru perlu merumuskan tujuan pembelajaran dan menyiapkan berbagai strategi yang berhubungan dengan pokok bahasan yang diajarkan.

2. Tahap pelaksanaan, guru menyajikan materi pelajaran dengan memanfaatkan pendekatan komunikatif, sehingga menarik perhatian siswa dalam proses belajar mengajar, sehingga pembelajaran berlangsung efektif dan efesien.

3. Tahap evaluasi, guru mengadakan evaluasi materi pelajaran yang lebih menekankan pada aspek kognitif dan afektif

Pendekatan komunikatif dapat juga diartikan sebagai pendekatan yang berpijak pada hakikat bahasa sebagai alat/sarana komunikasi, sehingga pengajaran bahasa diarahkan pada penggunaan bahasa sebagai alat komunikasi. Komponen komunikasi itu meliputi unsur pelaku komunikasi, cara berkomunikasi, tempat komunikasi, dan lain-lain.

Pendekatan komunikatif mengarahkan pengajaran bahasa pada tujuan pengajaran yang mementingkan fungsi bahasa sebagai alat komunikasi. Menurut pandangan ini, pengajaran membaca bertitik tolak pada pertanyaan, Mengapa seseorang membaca?

Sehubungan dengan pendapat itu, dia mengemukakan beberapa alternatif teknik pembelajaran Bahasa. Dalam kegiatan belajar-mengajar, siswa diberi latihan, antara lain seperti di bawah ini.

(1) Memberi informasi secara terbatas.

Contoh:

a. Mengidentifikasi gambar

Dua orang siswa ditugasi mengadakan percakapan tentang benda-benda yang terdapat dalam gambar yang disediakan oleh guru. Pertanyaan dapat mengenai warna, jumlah, bentuk, dan sebagainya.

b. Menemukan pasangan yang cocok 
Guru memberikan gambar kepada sekelompok siswa yang masing-masing mendapat sebuah gambar yang berbeda. Seorang siswa yang lain (di luar kelompok) diberi duplikat salah satu gambar yang telah dibagikan. Siswa ini mengajukan pertanyaan-pertanyaan kepada teman-temannya yang membawa gambar dengan tujuan untuk mengetahui indentifikasi atau ciriciri gambar yang mereka bawa. Dari hasil tanya jawab itu, siswa (pembawa duplikat) tersebut harus dapat menemukan siapa di antara teman-temannya itu yang membawa gambar yang cocok dengan duplikat yang dibawanya.

(2) Menemukan informasi tanpa dibatasi

Contoh:

Menemukan perbedaan

Siswa A dan B masing-masing mempunyai sebuah gambar yang sama, kecuali beberapa bagian. Para siswa harus mendiskusikan gambar tersebut sehingga menemukan perbedaannya.

(3) Menyusun informasi

Contoh:

Siswa diminta membayangkan bahwa mereka akan mengadakan kemah selama tiga hari. Tiap anggota hanya boleh membawa barang kira-kira $11 \mathrm{~kg}$. Kelompok-kelompok itu harus menentukan apa saja yang mereka bawa, dengan melihat barang yang patut dibawa, yang diberikan oleh guru, dan mempersiapkan pembelaan apabila mereka ditentang oleh kelompok lain.

Latihan-latihan tersebut merupakan latihan penggunaan Bahasa dalam aktivitas komunikasi yang bersifat fungsional dalam kelas. Di samping itu, juga terdapat aktivitas komunikatif yang lain, yakni: aktivitas interaksi sosial, dan simulasi dalam bermain peran.

Uraian di atas dapat diringkaskan sebagai berikut.

a. Pendekatan : Komunikatif

b. Teori dasar : Bahasa adalah alat komunikasi sosial.

c. Artinya : Bahasa itu bagi orang per orang adalah alat untuk mengungkapkan perasaan, pikiran, maksud, dan sebagainya kepada orang lain. Apa yang ada pada dirinya 
(misalnya informasi) disampaikan kepada orang lain agar orang lain pun memilikinya. Alat yang dipakai untuk menyampaikan itu adalah Bahasa.

Bahasa adalah salah satu alat yang dipakai orang untuk berkomunikasi. Alat yang lain masih banyak, misalnya: kentongan, gerak anggota tubuh, siulan, dan sebagainya.

d. implikasinya dalam kelas:

1. Harus ada interaksi verbal, baik antara guru dan siswa maupun siswa dan siswa.

2. Guru tidak usah terlalu banyak berbicara, menjelaskan, atau menggurui, tetapi menciptakan suasana yang baik agar siswa senang belajar dan senang berbicara.

3. Guru mendorong pengembangan kemampuan berko-munikasi siswanya. Lebih baik murid berani berbicara dan mengemukakan pandapat meskipun dengan Bahasa yang kurang baik dan kurang benar daripada diam karena takut salah.

4. hilangkan hambatan psikologis seperti takut salah, sungkan, malu, dan sebagainya.

5. beri tugas: masalah dan memecahkan masalah.

\section{Contoh:}

- berilah pelajaran yang bersifat bermain-main, kuis, teka-teki (seperti yang sering Anda tonton di televisi).

- upayakan agar siswa mau berbicara dan menggunakan Bahasa, apapun wujudnya. Bahasa Indonesia bercampur Bahasa Bali pun tidak apa-apa.

- suruh siswa mengajukan pertanyaan secara lisan. Bagi murid menjadi dua kelompok besar (deretan bangku): kelompok 1 bertanya, kelompok 2 menjawab, begitu bergantian.

- kembangkan imajinasi anak dengan Bahasa:

- andaikata saya menjadi .... 
- buat rangkaian cerita dari kata jarum sampai doa.

\section{SIMPULAN}

Pembelajaran adalah proses interaksi peserta didik dengan pendidik dan sumber belajar pada suatu lingkungan belajar. Pembelajaran merupakan bantuan yang diberikan pendidik agar dapat terjadi proses pemerolehan ilmu dan pengetahuan, penguasaan kemahiran dan tabiat, serta pembentukan sikap dan kepercayaan pada peserta didik. Dengan kata lain, pembelajaran adalah proses untuk membantu peserta didik agar dapat belajar dengan baik.Proses pembelajaran dialami sepanjang hayat seorang manusia serta dapat berlaku di manapun dan kapanpun. Pembelajaran mempunyai pengertian yang mirip dengan pengajaran, walaupun mempunyai konotasi yang berbeda.

Pendekatan komunikatif merupakan pendekatan yang dilandasi oleh pemikiran bahwa kemampuan menggunakan Bahasa dalam komunikasi merupakan tujuan yang harus dicapai dalam pembelajaran Bahasa (Zuchdi, 1997). Tampak bahwa Bahasa tidak hanya dipandang sebagai seperangkat kaidah, tetapi lebih luas lagi, yakni sebagai sarana untuk berkomunikasi. Ini berarti, Bahasa ditempatkan sesuai dengan fungsinya, yaitu fungsi komunikatif.

Pendekatan komunikatif didasarkan pada pemikiran, bahwa (1) pendekatan komunikatif membuka diri bagi pandangan yang lebih luas tentang Bahasa. Hal ini terutama menyebabkan orang melihat bahwa Bahasa tidak terbatas pada tata Bahasa dan kosakata, tetapi juga pada fungsi komunikasi Bahasa; (2) Pendekatan komunikatif membuka diri bagi pandangan yang luas dalam pembelajaran Bahasa. Hal itu menimbulkan kesadaran bahwa mengajarkan Bahasa, tidak cukup dengan memberikan kepada siswa bagaimana bentuk Bahasa, tetapi siswa harus mampu mengembangkan cara-cara menerapkan bentuk-bentuk itu sesuai dengan fungsi Bahasa sebagai sarana komunikasi dalam situasi dan waktu yang tepat.

Dalam pendekatan komunikatif, yang menjadi acuan adalah kebutuhan si terdidik dan fungsi bahasa. Pendekatan komunikatif berusaha membuat si terdidik memiliki kecakapan berbahasa. Dengan sendirinya, acuan pokok setiap unit pelajaran ialah fungsi bahasa dan bukan tata bahasa. Dengan kata lain, tata bahasa 
disajikan bukan sebagai tujuan akhir, tetapi sarana untuk melaksanakan maksud komunikasi.

\section{DAFTAR PUSTAKA}

Dibia, dkk. 2005. Pendidikan Bahasa Dan Sastra Indonesia Di Kelas Rendah Berorientasi Pada Kurikulum 2004, Singaraja: Fakultas Ilmu Pendidikan IKIP Negeri Singaraja.

Djuanda, Dadan. 2008. Studi Tentang Penerapan Pendekatan Komunikatif dan Pendekatan Terpadu dalam Pembelajaran Bahasa Indonesia di Kelas VI SD Negeri Sukamaju Kabupaten Sumedang. Terdapat pada http://file.upi.edu/Direktori/JURNAL/PENDIDIKAN_DASAR/Nomor_10Oktober_2008/Studi_Tentang_Penerapan_Pendekatan_Komunikatif_dan_P endekatan_Terpadu_dalam_Pembelajaran_Bahasa_Indonesia_di_Kelas_VI SD_Negeri_Sukamaju_Kabupaten_Sumedang.pdf. Diakses pada (28 September 2012).

Girsang, Bang. 2012. Model, Metode, Strategi, Pendekatan dan Teknik Pembelajaran. http//pelangi-iffah.blogspot.com/2011/04/metode-dalampembelajaran-bahasa.html. Diakses Pada Tanggal 28 September 2012

Zuchdi, Darmayanti dan Budiasih. 1997. Pendidikan Bahasa dan Sastra Indonesia Di Kelas Rendah. Jakarta: Departement Pendidikan Dan Kebudayaan.

Kusuma, 2008. Strategi Pendekatan Komunikatif dalam Menunjang Pembelajaran Keterampilan Berbicara. Terdapat pada http://sippendidikan.org/file_upload/Herianah\%20Strategi\%20Pendekatan\% 20Komunikatif.pdf. Diakses pada (28 September 2012). 